Scientia Marina 75(2)

June 2011, 251-262, Barcelona (Spain)

ISSN: 0214-8358

doi: $10.3989 /$ scimar.2011.75n2251

\title{
Revision of Hermodice Kinberg, 1857 (Polychaeta: Amphinomidae)
}

\author{
BEATRIZ YÁÑEZ-RIVERA and SERGIO I. SALAZAR-VALLEJO \\ El Colegio de la Frontera Sur, Unidad Chetumal, Av. Centenario km 5.5, 77900, Chetumal, Quintana Roo, México. \\ E-mail: beyariv7@gmail.com
}

\begin{abstract}
SUMMARY: The genus Hermodice Kinberg, 1857 was established with the species Aphrodita carunculata Pallas, 1766, based on the shape and development of the caruncle. Several species were later described within the genus; however, it is currently regarded as monotypical, with $H$. carunculata as a widespread species. An evaluation of available type and nontype specimens together with observations of living specimens has allowed the diagnostic features to be refined, and two new features have been included: the number of branchial filaments and the anal lobe. Consequently, in this study we have been able to confirm the differences between Hermodice and Pherecardia Horst, 1886. The type species, H. carunculata, has been redescribed, and $H$. nigrolineata Baird, 1870 has been re-established. Further, H. formosa (Quatrefages, 1866) has been transferred to Pherecardia, together with H. pennata Treadwell, 1906 and H. distincta Hoagland, 1920.
\end{abstract}

Keywords: caruncle, fireworms, morphological variability, taxonomy, Grand Caribbean, eastern Atlantic, Mediterranean Sea.

RESUMEN: Revisión del género Hermodice Kinberg, 1857 (Polychaeta: Amphinomidae). - El género Hermodice, Kinberg, 1857 se estableció con la especie Aphrodita carunculata Pallas, 1766, debido a la forma y desarrollo de la carúncula. Posteriormente, se describieron varias especies dentro del género. Sin embargo, actualmente se considera que el género es monotípico y que $H$. carunculata es una especie cosmopolita. La revisión de material tipo y especímenes adicionales, incluyendo ejemplares vivos, nos ha permitido redefinir las características diagnósticas e incorporar dos nuevos atributos: el número de filamentos branquiales y el lóbulo anal. Como consecuencia, ha sido posible confirmar las diferencias entre Hermodice y Pherecardia Horst, 1886. Así mismo, se redescribe la especie tipo $H$. carunculata y se reestablece $H$. nigrolineata Baird, 1870. Además, $H$. formosa (Quatrefages, 1866) se transfiere a Pherecardia, junto H. pennata Treadwell, 1906 y H. distincta Hoagland, 1920 .

Palabras clave: carúncula, gusanos de fuego, variabilidad morfológica, taxonomía, Gran Caribe, Atlántico oriental, mar Mediterráneo.

\section{INTRODUCTION}

Amphinomid polychaetes are commonly known as fireworms because of the burning sensation caused by their chaetae breaking after penetrating human skin. They are brightly colored and may reach large sizes (>50 cm long, $\approx 2 \mathrm{~cm}$ wide), as in the cases of some Eurythoe Kinberg, 1857 and Hermodice Kinberg, 1857 species. Fireworms thrive in the intertidal and may be abundant in coral reef or rocky areas; there are also some deep-water genera. Although several species are very large and colorful, the group has several taxonomic problems because its morphologic variability is poorly understood (particularly within closely related genera). In fact, several nominal species have been regarded as synonyms, often without an evaluation of the type materials. This might explain the presence of some widely distributed species (Salazar-Vallejo, 1997). Consequently, detailed revisions of species and even genera are needed (Kudenov, 1995), together with phylogenetic studies to clarify the affinities within the family (Wiklund et al., 2008). 
TABLE 1. - Taxonomic status of species considered in Hermodice.

\begin{tabular}{|c|c|c|c|c|}
\hline Species & Author & Taxonomic status & In Hermodice by: & Described in the genus: \\
\hline H. carunculata & (Pallas, 1766) & Valid & Kinberg, 1857, 1867, Baird, 1870 & Aphrodita \\
\hline H. savignyi & (Brullé, 1832) & junior synonym & Kinberg, 1867, Baird, 1870 & Amphinome \\
\hline H. striata & Kinberg, 1857 & Belong to Pherecardia & Kinberg, 1857, 1867, Baird, 1870 & Hermodice \\
\hline H. smaragdina & (Schmarda, 1861) & junior synonym & Kinberg, 1867 & Amphinome \\
\hline H. sanguinea & (Schmarda, 1861) & junior synonym & Kinberg, 1867, Baird, 1870 & Amphinome \\
\hline H. dydimobranchiata & (Baird, 1864) & junior synonym & Baird, 1870 & $\begin{array}{c}\text { Amphinome } \\
\text { after in Amphibranchus }\end{array}$ \\
\hline H. formosa & (Quatrefages, 1866) & Belong to Pherecardia & Kinberg, 1867 & Amphinome \\
\hline H. bruguieresi & (Quatrefages, 1866) & Belong to Pherecardia & Kinberg, 1867 & Amphinome \\
\hline H. picta & Kinberg, 1867 & nomen nudum & Kinberg, 1867 & Hermodice \\
\hline H. nigrolineata & Baird, 1870 & Valid & Baird, 1870 & Hermodice \\
\hline H. pennata & Treadwell, 1906 & Belong to Pherecardia & Treadwell, 1906 & Hermodice \\
\hline H. distincta & Hoagland, 1920 & Belong to Pherecardia & Hoagland, 1920 & Hermodice \\
\hline H. pennata tutuliensis & Treadwell, 1926 & Belong to Pherecardia & Treadwell, 1926 & Hermodice \\
\hline
\end{tabular}

Kinberg (1857) proposed Hermodice for H. striata Kinberg, 1857, from the Pacific island of Moorea, and to include Aphrodita carunculata Pallas, 1766, from the Lesser Antilles (Antigua). Later, Kinberg (1867) wrongly recognized Hermodice as a new genus, now with eight species: the two preceding ones, a new one from the Mediterranean Sea, H. picta Kinberg, 1867, and five formerly described in Amphinome Bruguière, 1789: $H$. savignyi (Brullé, 1832) from Moorea, H. smaragdina (Schmarda, 1861) and H. sanguinea (Schmarda, 1861) both from Jamaica, $H$. formosa (Quatrefages, 1866) from the Sandwich Islands, and $H$. bruguieresi (Quatrefages, 1866) from the Seychelles Islands. Kinberg (1867) also proposed Amphibranchus as a new genus that includes two species: A. occidentalis newly described from the Antilles (Barthelemy) and A. dydimobranchiata (Baird, 1864) from Ascension Island. Amphibranchus was subsequently regarded as a junior synonym of Hermodice, and its two species were regarded as junior synonyms of $H$. carunculata by Baird (1870), Fauvel $(1914,1923)$ and Hartman (1949).

Baird (1870) recognized only six species in Hermodice and described $H$. nigrolineata from the Mediterranean Sea and the Canary Islands, which was later synonymized with $H$. carunculata, as was $H$. savignyi (Fauvel, 1923; Ebbs, 1966).

Horst (1886) proposed Pherecardia for a new species: $P$. lobata, which had a large, foliose caruncle resembling that in Hermodice, although the folds were divergent and included a conspicuous median keel. Later, Horst (1911) indicated that several amphinomid species, including H. striata, should be transferred to Pherecardia. Regrettably, this was overlooked and consequently other species with a Pherecardia-like caruncle were described within Hermodice: H. pennata Treadwell, 1906 (Hawaii), H. distincta Hoagland, 1920 (Philippines), and the variety $H$. pennata tutuliensis Treadwell, 1926 (Samoa). Augener (1927) considered all these species as junior synonyms of $H$. striata without noticing that they should belong to another genus. Hartman (1949) emphasized that $H$. striata belonged to Pherecardia, and in her 1959 catalogue she listed these three species as probable synonyms of $P$. striata. However, Hartman did not evaluate her proposal with material revision.
As a result, most species in Hermodice have been regarded as junior synonyms of $H$. carunculata (Fauvel, 1923; Ebbs, 1966) (Table 1). Fauchald (1977) recognized four species (i.e. $H$. carunculata, widely distributed in the Atlantic, and the three questionable species included in the catalogue in Hartman (1959)). Nonetheless, besides the original descriptions, most records for the genus belong to $H$. carunculata (Fig. 1 ), which has been reported from shallow reef zones down to $300 \mathrm{~m}$ deep on sand flats (Ehlers, 1887; Ebbs, 1966).

This complex taxonomic background relies on synonymies that have mainly been proposed based on the available descriptions and illustrations rather than studies of type materials. Old descriptions, however, often lack complete characterizations of diagnostic characters. Therefore, in this paper, we present a systematic revision based on studying the available type material and including comparisons with additional material from different locations to propose a valid taxonomy for Hermodice and related genus.

\section{MATERIALS AND METHODS}

Specimens were borrowed from the following collections: The Natural History Museum, London (BMNH); Departamento de Zoología, Universidad de la Laguna, Tenerife (DZUL); Colección de Referencia, El Colegio de la Frontera Sur, Chetumal (ECOSUR); Museum of Faculty of Fisheries, Ege University, Turkey (ESFM); Institut de Recherche Fondamentale et Appliquée, Université Catholique de 1'Ouest, Angers (IRFA); Los Angeles County Museum of Natural History, Allan Hancock Foundation, California (LACMAHF); Muséum National d’Histoire Naturelle, Paris (MNHN); Swedish Museum of Natural History, Stockholm (SMNH); Texas Cooperative Wildlife Collection, Texas (TCWC); Colección de Referencia, Universidad de Nuevo León, Monterrey (UANL); National Museum of Natural History, Smithsonian Institution, Washington (USNM); Zoölogisch Museum, Universiteit van Amsterdam, Netherlands (ZMA).

Some standard measurements were made (body length, body width in chaetiger 10, and number of 


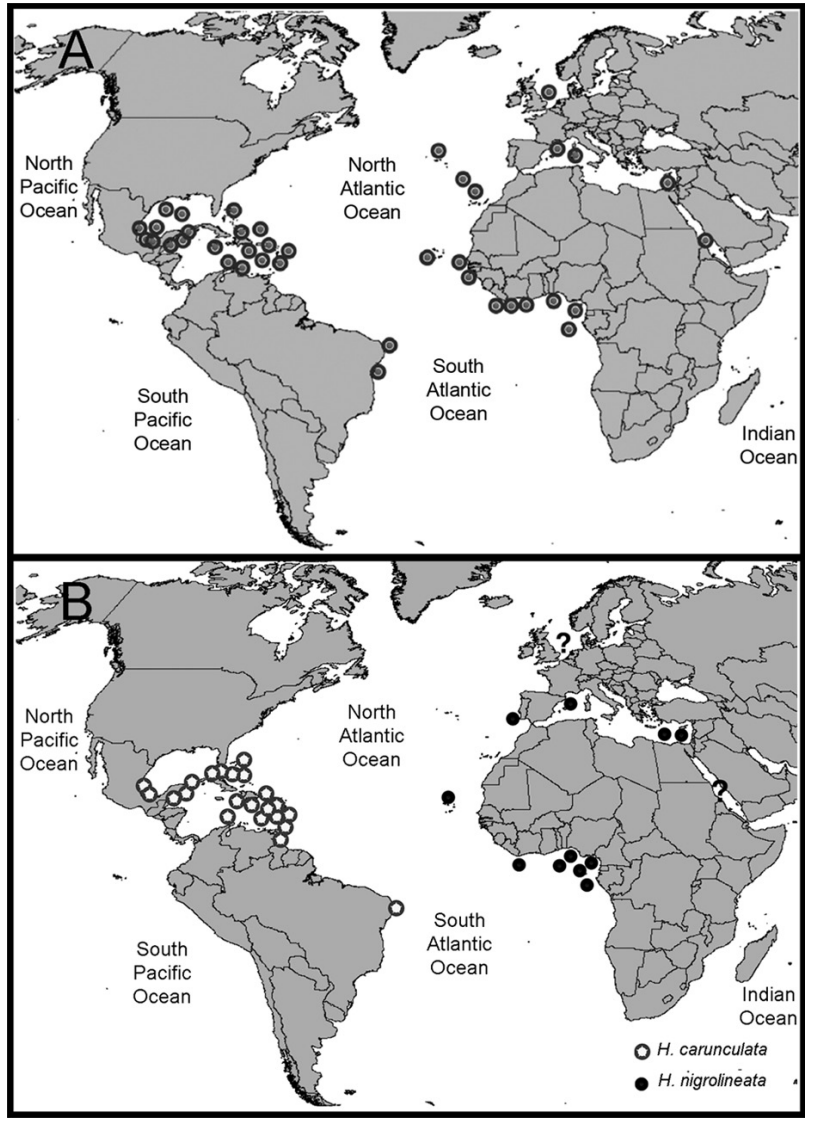

FIG. 1. - A, Hermodice carunculata records according to the literature. B, Hermodice species after this review, question marks indicate unavailable material. chaetigers). Further, we assessed the diagnostic potential of the median antenna length (MA), lateral antennae length (LA), palp length (PL), caruncle length $(\mathrm{CaL})$, caruncle width $(\mathrm{CaW})$, caruncular folds $(\mathrm{CaF})$, branchial filaments in the dorsal (DB) and lateral (LB) branches in chaetiger 10, cirrophore length $(\mathrm{CpL})$, cirrostyle length (CsL), ventral cirri length (VC), and anal lobe length (ALL) and width (ALW) (Fig. 2). The variability against body size (as number of chaetigers) was evaluated using the Prism 5.0c for Mac OS X, GraphPad Software, based on log-transformed data, and a power regression model was used to calculate the parameters of allometric relationship (Harvey and Pagel, 1991). Since two tendencies for branchial filaments were identified, the slopes of DB were compared with ANCOVA using the above-mentioned software. Semi-permanent slides of parapodia from chaetigers 10, 30 and 50 (often including some additional parapodia because chaetae may show different levels of erosion) were prepared to describe the chaetal denticulation.

The morphology of the caruncle was first described on living specimens, which were then fixed to study the possible modifications. Further, some histological sections were made and stained with Hematoxylin and Eosin to show muscular fibers in the caruncle. To provide a precise description of the caruncle morphology and its diagnostic features in Hermodice, materials belonging to Pherecardia from the LACM-AHF and USNM collections were borrowed for comparison.
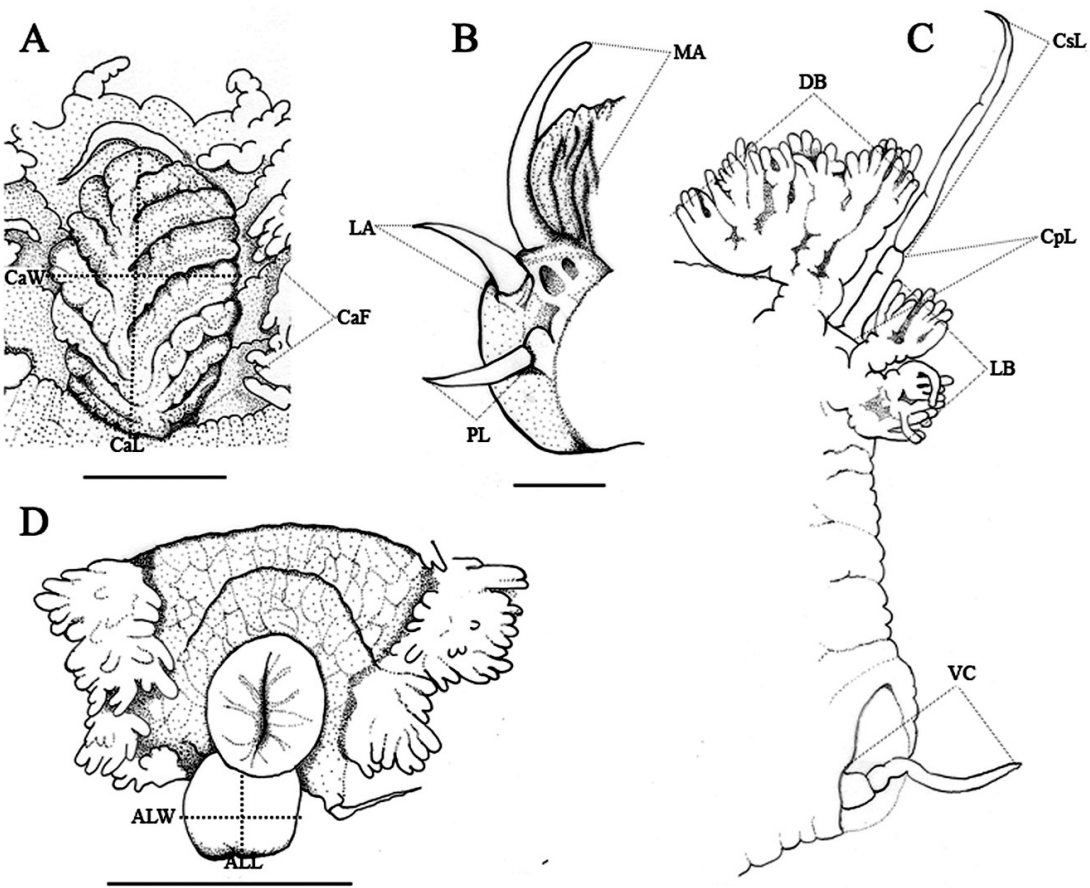

FIG. 2. - Morphological features evaluated in Hermodice: A, caruncle; B, prostomium; C, parapodium; D, pigydium. A scale: 1 mm; other scale: $0.5 \mathrm{~mm}$. Abreviations: ALL, anal lobe length; ALW, anal lobe width; CaF, caruncular folds; CaL, caruncle length; CaW, caruncle width; $\mathrm{CpL}$, cirrophore length; CsL, cirrostyle length; DB, branchial filaments in the dorsal branch in chaetiger 10; LA, lateral antennae length; LB, branchial filaments in the lateral branch in chaetiger 10; MA, median antenna length; PL, palp length; VC, ventral cirri length. 

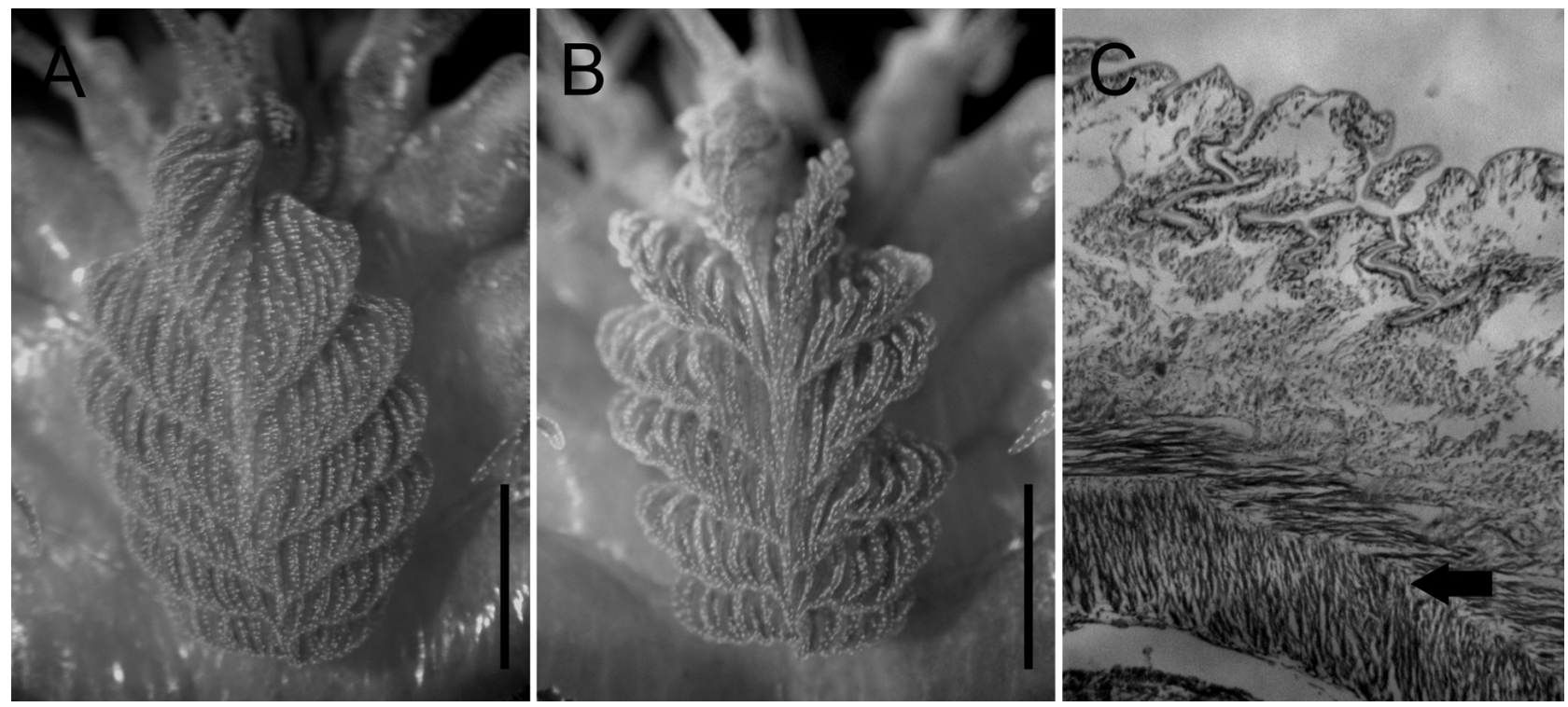

FIg. 3. - Hermodice caruncle: A and B same living worm; C, transverse section from median folds. Arrow: muscular fibers. Scale: $1 \mathrm{~mm}$.

\section{RESULTS}

\section{Morphological features}

\section{Prostomium}

After fixation, the prostomium is usually covered by the contraction of the first three chaetigers. On living animals, however, the prostomium projects forward beyond these anterior chaetigers. Thus, the contraction affects the relative eye-size and arrangement, which can only be correctly perceived by comparing dorsal and lateral views. Dorsally, the eyes are similarly sized and arranged in the corners of a rectangle, whereas laterally the posterior ones appear about half as large as the anterior ones. Hermodice eyes are complex, with well-developed optical nerves, a pigmented retina, a relatively homogeneous lens, and the underlying cuticle as a corneal layer (Marsden and Galloway, 1968). This complex structure may explain the observed differences in size, and that the pigmented areas appear to differ when seen from a single plane due to the different orientation of the eyes.

Prostomial appendages such as palps and antennae often show transverse marks, but these are irregular and depend on the contraction, so they are considered smooth. They show allometric relationships with the number of chaetigers, and vary greatly $\left(\mathrm{MA}=0.860 x-1.442, \mathrm{R}^{2}=0.688, \mathrm{n}=115\right.$; $\mathrm{LA}=1.036 x-1.964, \mathrm{R}^{2}=0.758, \mathrm{n}=139: \mathrm{PL}=0.752 x-1.553$, $\mathrm{R}^{2}=0.467, \mathrm{n}=86$ ). However, the median antenna always tends to be thicker and longer than laterals, and palps tend to be slightly smaller than lateral antennae.

\section{Caruncle}

This organ is widely employed to separate amphinomid genera and even species within the same genus.
However, the caruncle is made of a complex network of muscular filaments and nerves (Tovar-Hernández and Salazar-Vallejo, 2008), which is markedly altered during fixation (Fig. 3C). Living Hermodice specimens move the caruncle by contracting the longitudinal muscles, which makes the caruncular folds more prominent and better defined (Fig. 3A-B). Caruncle size depends on the number of chaetigers (Fig. 4A), and the length explains the variability better $\left(\mathrm{CaL}=1.019 x-1.430, \mathrm{R}^{2}=0.901, \mathrm{n}=130\right)$ than either width $\left(\mathrm{CaW}=1.067 x-1.695, \mathrm{R}^{2}=0.862, \mathrm{n}=118\right)$ or number of folds $\left(\mathrm{CaF}=0.044 x+0.041, \mathrm{R}^{2}=0.692, \mathrm{n}=133\right)$. Thus, the relative shape of the caruncle, which is ovoid or trapezoidal due to the natural movement, the length, the relative thickness or number of folds should not be employed as diagnostic features.

\section{Branchiae}

In Hermodice the relative position of the main branchial branches and the branching type are variable, and these variations and the relative branchial length have been employed in the past to establish additional species. However, this character is strongly affected by the relative contraction of successive chaetigers, so that branching patterns can be evaluated better in non-contracted than in contracted chaetigers. Contracted specimens will tend to have thicker and shorter filaments than non-contracted ones, so the real branching pattern will be easier to detect in the latter. The first three chaetigers have less branchial filaments and their number increases towards median chaetigers. The number of branchial filaments has an allometric relationship with the number of chaetigers, with two distinct patterns $(\mathrm{A}=1.614 x-1.127$, $\mathrm{R}^{2}=0.893, \mathrm{n}=91 ; \mathrm{B}=1.4 x-1.337, \mathrm{R}^{2}=0.576, \mathrm{n}=23$ ) and the differences are more pronounced in the dorsal branch (Fig. 4B) $(F=25.8322, \mathrm{P}<0.0001)$. 

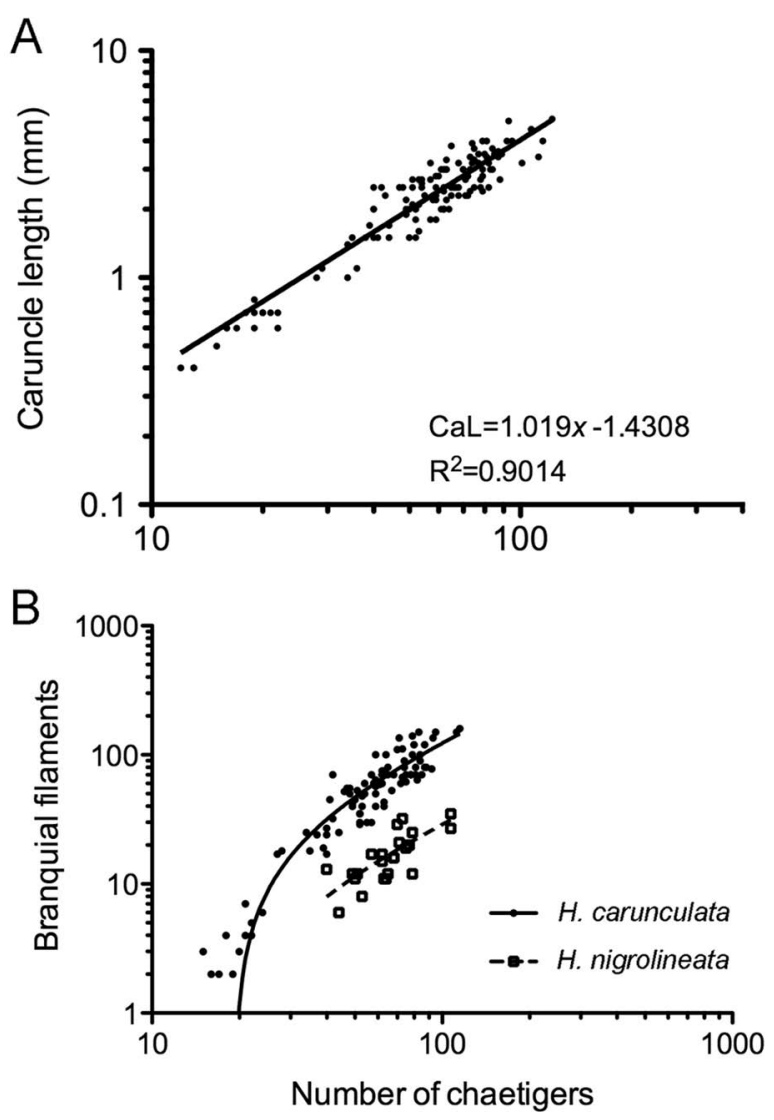

FIG. 4. - Morphological features in relation to the number of chaetigers: A, allometric relationship between caruncle and number of chaetigers; B, number of branchial filaments in the dorsal branchiae from two Hermodice species.

\section{Dorsal cirri}

Another usual diagnostic feature is the relative length of dorsal cirri in relation to chaetal length. However, chaetal sacs are retractable, which renders this attribute useless. Dorsal cirri length is also nonconsistent because cirri are muscular and contractile. However, the relative length of the cirrophores is relatively constant despite that the cirrostyle varies.

\section{Anal lobe}

The relative development of the anal lobes has not been previously employed as a taxonomic feature. This is a terminal, fleshy outgrowth showing two consistent patterns: it may be short and round or large and distally cleft (Figs. 5H, 6F). This character allows us to separate two species (see below).

\section{Chaetae}

Since chaetae are calcareous, erodible and employed for self-defense, their relative proportion should not be employed as a diagnostic feature. Harpoon chaetae in particular may be easily lost when employed for defensive purposes. Further, small variations in chaetal features must be used with caution because chaetal tips are easily eroded. Moreover, the traditional formalinsolution fixation becomes acidic, and thus alters the fine chaetal details (Fauvel, 1923). Consequently, the relevance of chaetae was considered to be rather minimal (Day, 1957). However, they could be employed after the variability along the body is defined. More specifically, the micro-scale regional differences in the distribution of each chaetal type in the chaetal lobe seem to be particularly relevant (Gustafson, 1930).

\section{SYSTEMATICS}

\section{Family AmpHINOMIDAe Savigny in Lamarck, 1818 Genus Hermodice Kinberg, 1857}

Hermodice Kinberg, 1857:12; Kinberg, 1910:35; Baird, 1870:219. Amphibranchus Kinberg, 1867:90.

Type species. Aphrodita carunculata Pallas, 1766, by subsequent designation (Hartman, 1949:41).

Diagnosis. Body large, rectangular in cross-section. Prostomium with four eyes and three antennae. Peristomium with two palps over dorsal lips. Caruncle massive, extending over three chaetigers, with oblique, convergent folds, without median keel. Branchiae from chaetiger 1, branching. Parapodia biramous; notopodia with single cirri. Anus dorsal with a terminal lobe. Notochaetae include serrate, long or short, and harpoon chaetae. Neurochaetae with smooth or denticulate spur chaetae, and more than ten aciculae.

Remarks. Kinberg (1910) redefined Hermodice as a new genus, but only included $H$. striata as a new species because the compilation for the Eugenie expedition series was prepared by someone else. However, the genus was proposed before (Kinberg, 1857) and $H$. carunculata was already included, as stated by Baird (1870) who also regarded Hermodice as a valid genus. $H$. carunculata was finally designated as the type species by Hartman (1949). However, this was overlooked by Ebbs (1966:518) who stated "type fixation unknown to me".

The alternating positions of parapodia along the body give the impression of duplicate branchiae (McIntosh, 1885), which might explain why Kinberg (1867) proposed including Amphibranchus based on Baird (1864)'s description of Amphinome dydimobranchiata as having a branchial pattern different enough to merit a distinct genus. However, Kinberg (1867)'s new genus overlooked its similarity to one of his previous genera. Baird (1870) noticed this problem, which might explain the omission of Amphibranchus, and the transfer of his own species to Hermodice.

Since the original proposal for Hermodice, the genus has not been rejected. However, it contains several species that might correspond to Pherecardia due to their caruncle type (Horst, 1911), which differs from 
that of Hermodice in having diverging folds and a well developed median keel.

Accordingly, our revision of type and topotype materials, together with the original descriptions, indicates that the following nominal Hermodice species should be transferred to Pherecardia: 1) H. pennata, 2) $H$. pennata tutuliensis, 3) $H$. formosa, and 4) $H$. bruguieresi. However, H. picta should be regarded as a nomen nudum (Table 1).

\section{Hermodice carunculata (Pallas, 1766)} (Fig. 5)

Aphrodita carunculata Pallas, 1766:102-106, Fig. 12-13.

Amphinome carunculata Bruguière, 1789:46-47 (n. comb.); Audouin and Milne Edwards, 1833:197; Quatrefages, 1866:395-397.

Pleione carunculata Savigny, 1822:61-62 (n. comb.).

Hermodice carunculata Kinberg, 1857:13 (n. comb.); Kinberg, 1867:89; McIntosh, 1885:24-27; Ehlers, 1887:27-29; Treadwell, 1939:173-175, Fig. 8; Hartman, 1949:41-42; Hartman, 1951:22-25, Pl. 5, Fig. 1; Ebbs, 1966:518-524, Fig. 8; Ibarzábal, 1989:13-14, Fig. 7; Liñero-Arana, 1993:24, Pl. 6, Figs. 1-7; Salazar-Vallejo, 1997:383, Figs. 3, 9, 12 (all with descr.).

Amphinome smaragdina Schmarda, 1861:140, Pl. 34, Fig. 288; Quatrefages, 1866:405.

Amphinome sanguinea Schmarda, 1861:140, Pl. 34, Fig. 289; Quatrefages, 1866:405.

Amphinome dydimobranchiata Baird, 1864:449-450, Figs. 1-7. Amphibranchus occidentalis Kinberg, 1867:90.

Type material: Holotype of Amphibranchus occidentalis Kinberg, 1867 [SMNH-1257]. Barthelemy. Syntypes of Amphinome dydimobranchiata Baird, 1864 [BMNH-1983.11.6.2]. Ascension Island, Coll. Mr. Watson; (4) damaged.

Additional materials. Netherland Antilles, [ZMA] Aruba: Sta. 1003, Lagoen Boekoeti, Oranjestad, sand-limestone, 1 m, 1930 (2); Sta. 1116B, Gallows Bay, rocky bottom, 1-2 m, 1949 (1). Bonaire: Sta. 1057a, Kralendijk, rocky shore, 1 m, 1930 (3). Curaçao: Boeke, 1905 (2); 1906 (1); Sta. 1323, Santa Marta Baai, lagoon, 1955 (3); Sta. 1029, Piscadera Baai, rocky shore, 1.5 m, 1949 (1); Sta. 1029A, tide-pool (9); Sta. 1453, Mouth NE, 3.5 m, 1964 (12); Sta. 1017, Knip Baai S, 0.5 m, 1949 (1) damaged; Sta. 1666A, Awa di Oostpunt, 30-50 m offshore, sand, $1 \mathrm{~m}, 1970$ (1); [LACM-AHF] Sta. A46-39, shore, (1); [USNM-4643] (3); R/V Albatross, 1884 (4). [ZMA] Klein Bonaire: Sta. 1367 W, rocky shore, 1 m, 1955 (1). Saint Martin: Sta. 1125, Great Bay, rocky shore, 0.5 m, 1949 (2). Bahamas, Bimini: Sta. 1150A, Massy Creek S, sand, 1 m, 1949 (1). [USNM-3904] New Providence: R/V Albatross, 1886 (9). Barbados, [USNM-31034] $13.2^{\circ} \mathrm{N}, 59.5^{\circ} \mathrm{W}$, coral rocks, $1-3 \mathrm{~m}, 1962$ (3). Brazil, [USNM-15867] Alagoas, coral reefs, 1899 (1). British Overseas Territories, Anguila: [ZMA] Sta. 1142, rocky shore, 0.5 m, 1949 (2). Bermuda: [USNM-4781] 32. $3^{\circ} \mathrm{N}, 64.8^{\circ} \mathrm{W}, 1876$ (3). Colombia, [LACM-AHF] Honda Bay, 15 m (1); [USNM-20503] Providencia Island, Presidential Cruise Expedition, Sta. 30, 1938 (4). Florida, [LACM-AHF] Harbor Branch, 21.6 m, 1975 (2); Biscayne Bay,

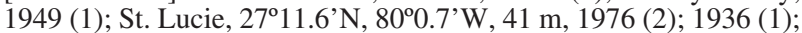
Lake Worth, 1936 (1). Virgin Islands, [USNM-1656] St. Thomas, R/V Albatross, 1884 (4); [TCWC-1-2269] St. Croix, Isaac Bay, 1973 (1). Jamaica, [USNM-1646] R/V Albatross, 1884 (4); [USNM31035] Kingston Harbour, Port Royal, 1961 (2); [ZMA] Sta. 1683, Drunkemans N, sand and debris, $1 \mathrm{~m}, 1973$ (1). Mexico, [ECOSURAMPI-3] Quintana Roo: Ascension Bay, 19³6’N, 8744'W, 1988 (2); Chichorro Cay, Sta. EL-2774, $18^{\circ} 45^{\prime} \mathrm{N}, 87^{\circ} 15^{\prime} \mathrm{W}, 52 \mathrm{~m}$, 1990 (1); Contoy Island, $21^{\circ} 28^{\prime} \mathrm{N}, 8^{\circ} 47^{\prime} \mathrm{W}, 1999$ (1); 2001 (8); Cozumel Island, $20^{\circ} 19^{\prime} \mathrm{N}, 8^{\circ} 02^{\prime} \mathrm{W}, 1960$ (1); 2001 (4); Sta. EL2772, 2039'N, 86²9'W, 160 m, 1990 (1); Gavilan Point 18²1'N, $87^{\circ} 47^{\prime} \mathrm{W}, 1992$ (1); Herrero Point S, Sta. EL-2789-4, 19¹3'N, $87^{\circ} 30^{\prime} \mathrm{W}, 1990$ (1); Indio River, $18^{\circ} 48^{\prime} \mathrm{N}, 87^{\circ} 40^{\prime} \mathrm{W}$, reef lagoon,

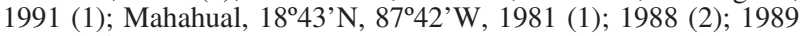
(1); 1996 (3); 1997 (1); 1998 (1); 2000 (4); Sta. EL-2783, 1841’N, $87^{\circ} 41^{\prime} \mathrm{W}, 58 \mathrm{~m}, 1990$ (1); Morelos Port, 2050'N, 8652'W, 3-4 m,

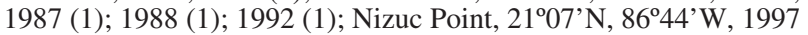

(1); Xahuayxhol, $18^{\circ} 30^{\prime} \mathrm{N}, 8^{\circ} 45^{\prime} \mathrm{W}, 1999$ (3); Xcacel, 2020’ N, $80^{\circ} 20^{\prime} \mathrm{W}, 1992$ (1); 1995 (1); 2005 (1); Xcalak, $18^{\circ} 15^{\prime} \mathrm{N}, 8^{\circ} 49^{\prime} \mathrm{W}$,

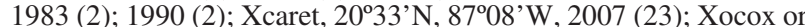
Chacom Point, Sta. EL-2784, 1846’N, 87³4'W, 57 m, 1990 (1); 1991 (1); Xoquem Point, 19²49’N, 87²7’W, 1986 (1); 1991 (1). Veracruz, Santiaguillo, 1957 (1); [UANL-0016] Cazonez, 1973 (1); [UANL-0638] Tuxpan, 1974 (1); [UANL-0637] 1977 (1). Panama, [LACM-AHF] Bastimentos Island N, Sta. F-1001/BDT-3, coral rubble, $10 \mathrm{~m}, 2003$ (3); Bocas del Toro, $9^{\circ} 13.34^{\prime} \mathrm{N}, 8^{\circ} 15.24^{\prime} \mathrm{W}$, coral rubble, 16 m, 2003 (1); Caledonia Bay, Sta. A8-39, 1939 (2); Sta. A57-39 (4); Sta. A50-39 (1); Sta. A2-39 (3); Fort Randolf, reef lagoon, 1972 (2); San Blas, Porvenir, 1969 (1); Pina Beach, rocky shore, 1969 (1). Puerto Rico, [LACM-AHF] La Parguera, 16 m, 1955 (1); Mayaguez, 1945 (2). Saint Lucie, [ZMA-VPOL0421] Port de Castrie, Exp. Chazalie, 1906, (2). Trinidad and Tobago, [LACMAHF] Tobago coast, Sta. A4139 (6).

Description. Body complete [Topotype ZMAunnumb.], long, truncated at ends, $4.5 \mathrm{~cm}$ long, 0.6 $\mathrm{cm}$ wide, 62 chaetigers. Prostomium semicircular with four eyes, anterior larger, dark reddish. Median antenna (0.7 mm long) central, longer and thicker than lateral antennae $(0.4 \mathrm{~mm}$ long), placed on anterior prostomial margin. Palps slightly smaller $(0.3 \mathrm{~mm})$ than lateral antennae, placed ventrally and externally to antennae in a swollen area running from lips (Fig. 5A). Mouth placed ventrally between chaetigers 3 and 4 . Caruncle oval ( $2 \mathrm{~mm}$ long, $1.5 \mathrm{~mm}$ wide) with seven convergent folds, each carrying some irregular constrictions or striae (Fig. 5B).

Branchiae from chaetiger 1, present throughout body. Each branchia has two main branches, dorsal (DB) and lateral (LB), DB with more branchial filaments (Fig. 5D, E); total branchial filaments per chaetiger as follows: 1 with $7(\mathrm{DB}=4, \mathrm{LB}=3) ; 2$ with 15 $(\mathrm{DB}=10, \mathrm{LB}=5) ; 3$ with $26(\mathrm{DB}=17, \mathrm{LB}=9) ; 10$ with $87(\mathrm{DB}=72, \mathrm{LB}=15)$; median chaetigers with approximately $94(\mathrm{DB}=80, \mathrm{LB}=14)$; posterior chaetigers showing a decreasing trend in branchial filaments; far posterior chaetigers with $50(\mathrm{DB}=45, \mathrm{LB}=5)$.

Parapodia biramous, massive, each ramus with a single cirrus (Fig. 5C). Dorsal cirri with long cirrophore $(0.5 \mathrm{~mm}$ long), cirrostyle thinner, longer $(1 \mathrm{~mm}$ long), becoming smaller and thicker in some chaetigers (Fig. 5I). Ventral cirri digitate, larger in anterior than in posterior chaetigers.

Pygidium truncate, anus dorsal, with a distal lobe wider than long ( $0.2 \mathrm{~mm}$ long, $0.3 \mathrm{~mm}$ wide), margin smooth (Fig. 5H).

Notochaetae as harpoon chaetae and simple capillaries with tiny denticles of varying shape: basal ones triangular, wide, short, widely separated from each other; distal ones sharper, abundant, forming irregular continuous rings (Fig. 5F, G). Neurochaetae with or without a spur, but with denticulated distal margin, with 4-25 denticles per chaetae. Neuroaciculae lanceshaped, in a single series.

Variation. Size range: 12-130 chaetigers, from $0.25 \mathrm{~cm}$ long and $0.15 \mathrm{~cm}$ wide up to $25 \mathrm{~cm}$ long and $2.5 \mathrm{~cm}$ wide. Prostomium: median antenna 0.1-2.0 $\mathrm{mm}$ long, lateral antennae 0.1-1.3 mm, palps: 0.1-0.8 $\mathrm{mm}$. Caruncle: size dependent, having 3-10 folds (0.4- 

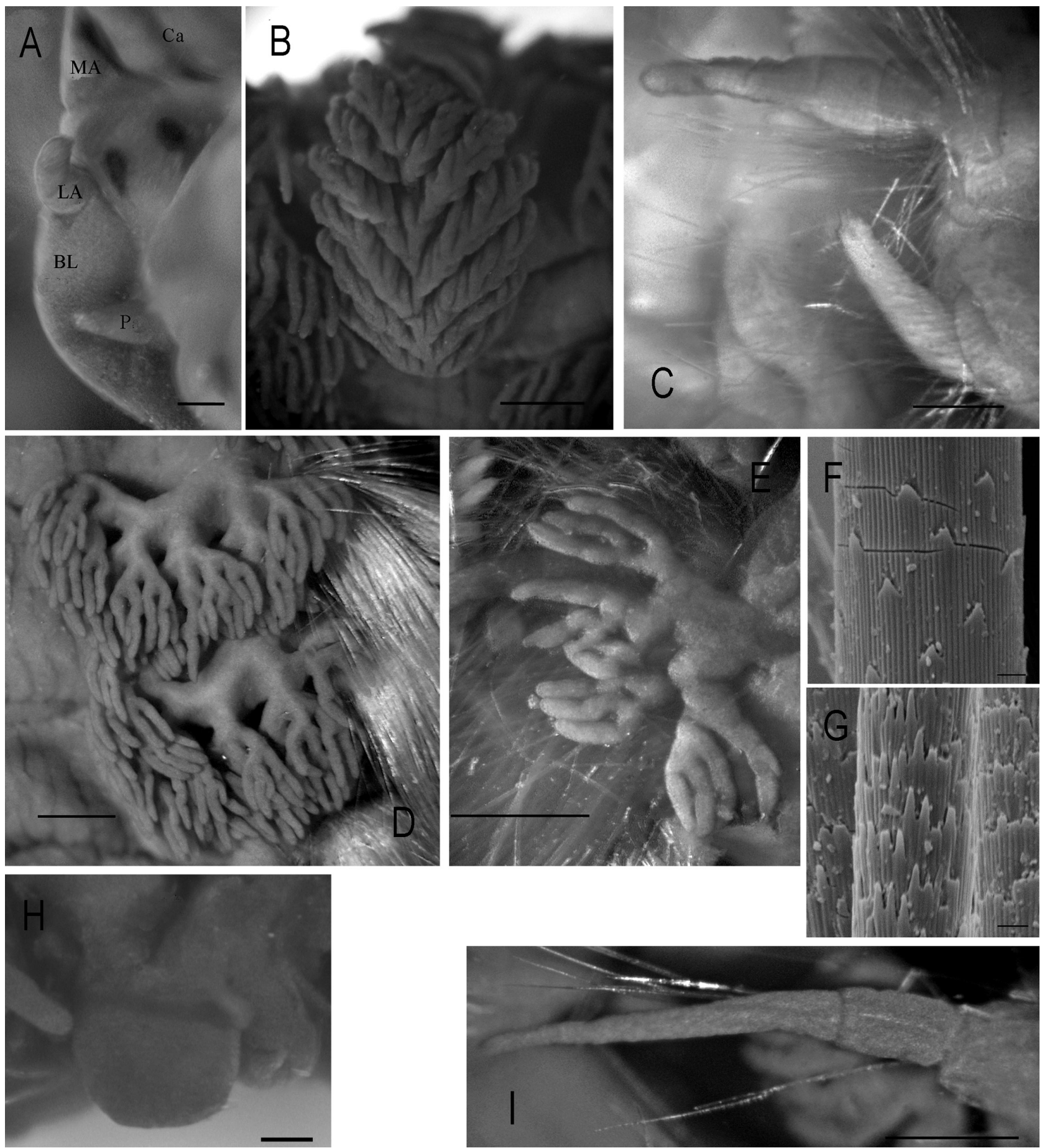

FIG. 5. - Hermodice carunculata: A, prostomium, lateral view; B, caruncle, dorsal view; C, parapodium; D, branchial dorsal branch; E, branchial lateral branch; F, distal surface of capillary notochaeta; G, basal surface of capillary notochaetae; H, anal lobe, view after displacement; I, dorsal cirrus. A and C scale: $0.2 \mathrm{~mm}$; B, D, E, and I scale: $0.5 \mathrm{~mm}$; F and G scale: $2 \mu \mathrm{m}$; H scale: $1 \mathrm{~mm}$. Abbreviations: BL, buccal lip; Ca, caruncle; LA, lateral antenna; MA, median antenna; and P, palp.

$3.7 \mathrm{~mm}$ long, 0.1-2.7 $\mathrm{mm}$ wide); sometimes with a tenuous, thin, median elevation, but never with a welldeveloped median keel; oval to trapezoidal in shape, depending on fixation, since it is very muscular and movable. Branchiae: 12-chaetiger specimens with only 2-3 branchial filaments on chaetiger 10; $>100$-chaetiger specimens with over 150 filaments only on the dorsal branch. A $>50$-chaetiger specimen (about $4 \mathrm{~cm}$ long) had about 70 filaments ( $\mathrm{DB}=55, \mathrm{LB}=15)$. Branchial branch separation varies and depend on the alternating elevation of successive chaetigers and specimen contraction. Only branchial bases were left on damaged specimens, they lost terminal filaments. Parapodia: Dorsal cirri along first chaetigers slightly thicker, es- 
pecially in larger specimens, showing an irregularly wrinkled cirrophore. Cirrostyle length ranging from 0.6 to $2.7 \mathrm{~mm}$ long. Pygidium: Anal lobe often with a distal, median contraction, or with a diffuse dark pigmentation, always with abundant white or dark spots on living specimens (frequently lost after fixation). Chaetae: Relative size of notochaetae varying both in length and width. Neurochaetae with marked differences in number of marginal teeth, very often with a basal spur. Denticles on chaetal tips often blunt or even round due to erosion. Pigmentation: Living specimens vary from orange to dark red, purple or deep green, often with inter-segmental, dorsal lines surrounded by a thick yellow band (often lost after fixation), or with a longitudinal, mid-dorsal, darker brown band (also often lost after fixation). One specimen had a rather irregular pigmentation pattern probably due to an integument infection. Transverse black band absent in some specimens, as it may be lost after fixation but can be retained for as long as 10 to $20 \mathrm{yr}$. Living specimens with white spots in branchiae, prostomium and caruncle, absent from preserved worms.

Remarks. The descriptions of A. smaragdina and A. sanguinea from Jamaica (Schmarda, 1861) emphasized the color variations, especially on branchiae, as indicated by the species epithet: emerald green in the former, deep red in the latter. The names of these species were based on large specimens $(>15 \mathrm{~cm})$, but the caruncle shape and branching patterns were defined only for A. sanguinea. However, since there is wide variation in pigmentation, the caruncle can be modified by contraction, and the reviewed Jamaican specimens did not differ from $H$. carunculata, these nominal species are regarded as junior synonyms of this species.

A figure in the original description of A. dydimobranchiata (Baird. 1864) shows some small teeth under the spur of harpoon chaetae. However, these small denticles were not observed in the present study, and taking into account that physical or chemical damage can shatter chaetal surfaces and also due to the lack of other differences $A$. dydimobranchiata is also regarded as a junior synonym of $H$. carunculata.

The branchial pattern led Kinberg (1867) to propose A. occidentalis, but the similarity with the caruncle of Hermodice was overlooked. Lateral branchial branches may be difficult to observe as they might be hidden behind chaetal lobes and Baird (1870)'s revision disregarded A. occidentalis (it was probably regarded as invalid, but there were no further comments). Since the position and visibility of the lateral branchial branch is variable and the observed materials share all the morphological features of $H$. carunculata, A. occidentalis is regarded as a junior synonym.

Gametes. Gametes are present in the coelom in females once they have over 50 chaetigers, and in males that have more than 80 chaetigers; mature specimens were collected in February (1\%), March (1 9 ) and June
$(9 q, 2 \AA)$. Oocytes were in various degrees of development, and were $97 \pm 16 \mu \mathrm{m}$ in diameter $(n=100)$. Spermatozoids were aggregated in masses, each had a protective shield, a spherical head plus mitochondria, and a long tail. This corresponds to a primitive type, probably related to external fertilization.

No sexual dimorphism was found. Gametes were seen in specimens with over 50 chaetigers. A previous account of sexual maturity in smaller specimens (Salazar-Vallejo, 1997) was incorrect; the specimen was re-analyzed and there were no oocytes or sperm. The observed particles were probably from the gut.

Pigmentation. Despite the different pigmentation patterns (Savigny, 1822; Ehlers, 1887; Ibarzábal, 1989) and their use to separate species (Schmarda, 1861), they do not correspond with a valid taxonomical explanation. Savigny (1822) noticed transverse black band in the largest specimens only, while Ehlers (1887) regarded pigment variations as age dependent. Kudenov (1974) found that E. complanata (Pallas, 1766) adult males were whitish whereas mature females were pink or reddish, which reflects the abundance of gametes. In $H$. carunculata, different colorations were found in animals of similar sizes or even in mature females. Thus, physiological or genetic studies are necessary to clarify the reasons behind this variability and determine its taxonomic usefulness.

Anomalies. Seventeen out of 198 specimens (8.5\%) had malformations. Two had anterior eyes smaller than the posterior ones. Two had the pigment scattered in the eye area but no eyes. Several had some appendices doubled: lateral antenna (1), palps (1), dorsal cirri (10) and cirrophore (1). Double dorsal cirri are restricted to 1-5 chaetigers. Some specimens had a very small dorsal anal lobe, which could result from an incomplete regeneration. Malformations have been previously reported in other amphinomids, such as E. complanata (Barroso, pers. com.) as well as H. carunculata (a double ventral cirrus in Liñero-Arana, 1993). In addition, some irregular regeneration was indicated by double parapodia on one side of a single chaetiger.

Questionable records. After examining some deepwater material, the specimens were revealed to belong to different genera or even families, especially those collected below $100 \mathrm{~m}$. The Fauvel and Rullier (1959) record of $H$. carunculata from 100-109 m corresponds to a Linopherus sp., and the Hermodice [MNHN] specimens from $850 \mathrm{~m}$ deep are actually aphroditids. The report of Ehlers (1887) from $323 \mathrm{~m}$ deep probably belongs to a juvenile specimen and must be regarded with care because the deepest record for a juvenile confirmed with the observed material is $70 \mathrm{~m}$ deep.

Hartman (1951) illustrated a Pherecardia striata probably collected in the Gulf of Mexico. However, Pherecardia is restricted to the Pacific Ocean while Hermodice is apparently restricted to the Atlantic Ocean. Further, Salazar-Vallejo and Londoño-Mesa 
(2004) wrongly included two records of $H$. carunculata for the tropical eastern Pacific and the only previous record for this region, from Port Parker $\left(10^{\circ} 55^{\prime} \mathrm{N}\right.$, $85^{\circ} 48^{\prime} \mathrm{W}$ ) in Costa Rica (Treadwell, 1941), did not provide sufficient details and therefore it has been regarded as questionable (Dean, 2004).

\section{Hermodice nigrolineata Baird, 1870} (Fig. 6)

Hermodice nigrolineata Baird, 1870:220-221.

Hermodice carunculata Fauvel, 1914:88; Rullier, 1964:143-144 (partim, non Pallas, 1766).

Hermodice carunculata dydimobranchiata Fauvel, 1914:113-116; Monro, 1930:42; Tebble, 1955:83.

Type material. Holotype of Hermodice nigrolineata Baird, 1867 [BMNH-1887.7.27.72]. Egyptian coast, near Alexandria, Coll. R.M. Andrew; damaged material, five fragments, probably belonging to two specimens.

Additional material. Cape Verde, [MNHN] Without data (3), Calypso Sta. 34 (1), Sta. 50 (2), Sta. 69 (2). Gulf of Guinea, [MNHN] Gabou, 9-5 (1), Calypso Sta. 68, 0-6 m, 1956 (3), Sta. 127, 127 m, 1956 (1), Cape Lopez, 1989 (1), Gerard Tréca Sta. 42, 905’ N, $15^{\circ} \mathrm{W}, 75-80$ m, 1953 (1), Saô Joâo dos Angolares, 1906 (1); [IRFA] Ombago, 30 m, 1960 (1), Uohomey, 45.5 m, 1964 (1). Egypt, [MNHN] Alexandria, 1933 (2). Spain, [DZUL] Canary Islands, Tenerife, Poni de Abona, 6 m, 2005 (1), Las Eras, 6.5 m, 2005 (6) Portugal, [MNHN] 200 m from Graciosa, Sta. 238, 95 m, 1998 (1). Turkey, [ESFM-POL-501] Kumluca Karaóz Limani 36¹6'32'N, $30^{\circ} 24^{\prime} 15^{\prime \prime} \mathrm{E}$, rocks, 1-3 m, 2005 (8); [ZMA-unnumb.] the same data, donated by Melih Cinar.

Description. Body complete [Topotype ZMAunnumb.], truncate at both ends, $7 \mathrm{~cm}$ long, $1 \mathrm{~cm}$ wide, 68 chaetigers. Prostomium semicircular with two pairs of dark eyes, anterior ones larger. Three antennae, median one longer and thicker (1 $\mathrm{mm}$ long) placed in anterior prostomial region; lateral antennae $(0.7 \mathrm{~mm}$ long $)$ placed on anterior prostomial margin. Palps slightly smaller (0.6 mm long), ventral and external to lateral antennae (Fig. 6A). Mouth ventral, between chaetigers 2 and 4. Caruncle oval (2.5 $\mathrm{mm}$ long, $2 \mathrm{~mm}$ wide), with seven convergent caruncular folds (Fig. 6B).

Branchiae from chaetiger 1, extending throughout the entire body; each branchia with a dorsal (DB) and a lateral branch (LB), both with a few filaments (Fig. $6 \mathrm{D}, \mathrm{E})$, gradually increasing in DB towards median region and remaining almost without change posteriorly; relatively constant in LB. Total branchial filaments per chaetiger as follows: 1 with $5(\mathrm{DB}=3, \mathrm{LB}=2) ; 2$ with $12(\mathrm{DB}=6, \mathrm{LB}=6) ; 3$ with $15(\mathrm{DB}=7, \mathrm{LB}=6) ; 10$ with $27(\mathrm{DB}=16, \mathrm{LB}=11)$; median chaetigers with 26 $(\mathrm{DB}=18, \mathrm{LB}=8)$; posterior region with about 30 filaments $(\mathrm{DB}=21, \mathrm{LB}=7)$.

Parapodia biramous, massive, each ramus with one cirrus (Fig. 6C). Dorsal cirri with short cirrophore (0.3 $\mathrm{mm}$ long); cirrostyle thin, long (1.5 mm long) (Fig. 6G). Ventral cirri prominent.

Pygidium truncate, anus dorsal with an anal lobe markedly longer than wider $(0.5 \mathrm{~mm}$ long, $0.2 \mathrm{~mm}$ wide), posterior margin with a distal notch, apparently bilobulate (Fig. 6F).
Harpoon and long or short capillary chaetae, with non-visible denticulation. Serrated notochaetae often with spur, with 3,4 or up to 30 distal denticles. Aciculae in a single series.

Variation. Body size: 44 to 107 chaetigers and from $2 \mathrm{~cm}$ long, $3.5 \mathrm{~mm}$ wide to $25 \mathrm{~cm}$ long, $1.4 \mathrm{~cm}$ wide). Prostomium: median antenna: $0.5-2.8 \mathrm{~mm}$ long, lateral antennae: $0.4-1.5 \mathrm{~mm}$ long, palps: $0.3-1.3 \mathrm{~mm}$ long. Caruncle: With 6 or 7 folds (1.5-3.3 mm long, 1.0-2.4 mm wide); mostly oval; two specimens with more projected folds (probably resulting from regeneration). Branchiae: Branchial filaments less numerous than in $H$. carunculata. A 50-chaetiger specimen, about $4.5 \mathrm{~cm}$ long had 25 filaments $(\mathrm{DB}=18, \mathrm{LB}=7)$, while $\mathrm{a} \approx 100$ chaetiger specimen about $17 \mathrm{~cm}$ long had about 30 filaments ( $\mathrm{DB}=19, \mathrm{LB}=9$ ). Parapodia: Dorsal cirri 0.7-2 mm long. Dorsal cirrophore short, even in large specimens, reaching up to $0.4 \mathrm{~mm}$ in length; dorsal cirrostyle variable, although thinner than in $H$. carunculata, and often reflexed. Pygidium: regardless of their relative size, all specimens had a rectangular anal lobe, markedly longer than wider and with distal margin bilobed. Chaetae: besides varying in distal denticle number, chaetal tips are rounded, probably as a result of abrasion. Pigmentation: all specimens with a transverse, dorsal, intersegmental black line.

Remarks. The species name refers to the presence of a transverse, dorsal, intersegmental black line, which is not exclusive for the species (as noted above). The original description emphasized the caruncular resemblance to $H$. carunculata (Baird, 1870), and the species was regarded as a junior synonym of $H$. carunculata (Hartman, 1959; Ebbs, 1966), particularly after observing that some juvenile specimens from Florida have intersegmental black lines (Ebbs, 1966). However, Baird (1870) indicated that the branchiae were clearly less developed than in $H$. catunculata, as they have just a few branched filaments, although this feature has not been employed before to separate species.

All examined specimens had the dorsal, transverse, black line, which was previously reported for a few specimens collected in the Mediterranean or Azores (Fauvel, 1914). The specimens from Cabo Verde had a dorsal pigmentation ranging from a pale background with emerald-green transverse band to a metallic blue, including ochre or green variations, but all of them showed the transverse, dorsal, black, intersegmental band (Rullier, 1964). Other published photographs of $H$. nigrolineata show orange to a dark dorsal pigmentations, with a yellow and black complex, transverse, dorsal band (Monterroso et al., 2004).

Fauvel (1914) found species up to $129 \mathrm{~m}$ deep, but only some of them from $95 \mathrm{~m}$ deep were analyzed here. Finally, some juveniles have been found in Dendrophyllia coral bottoms off the Canary Islands (Nuñez et al., 1991) at $108 \mathrm{~m}$ deep. 

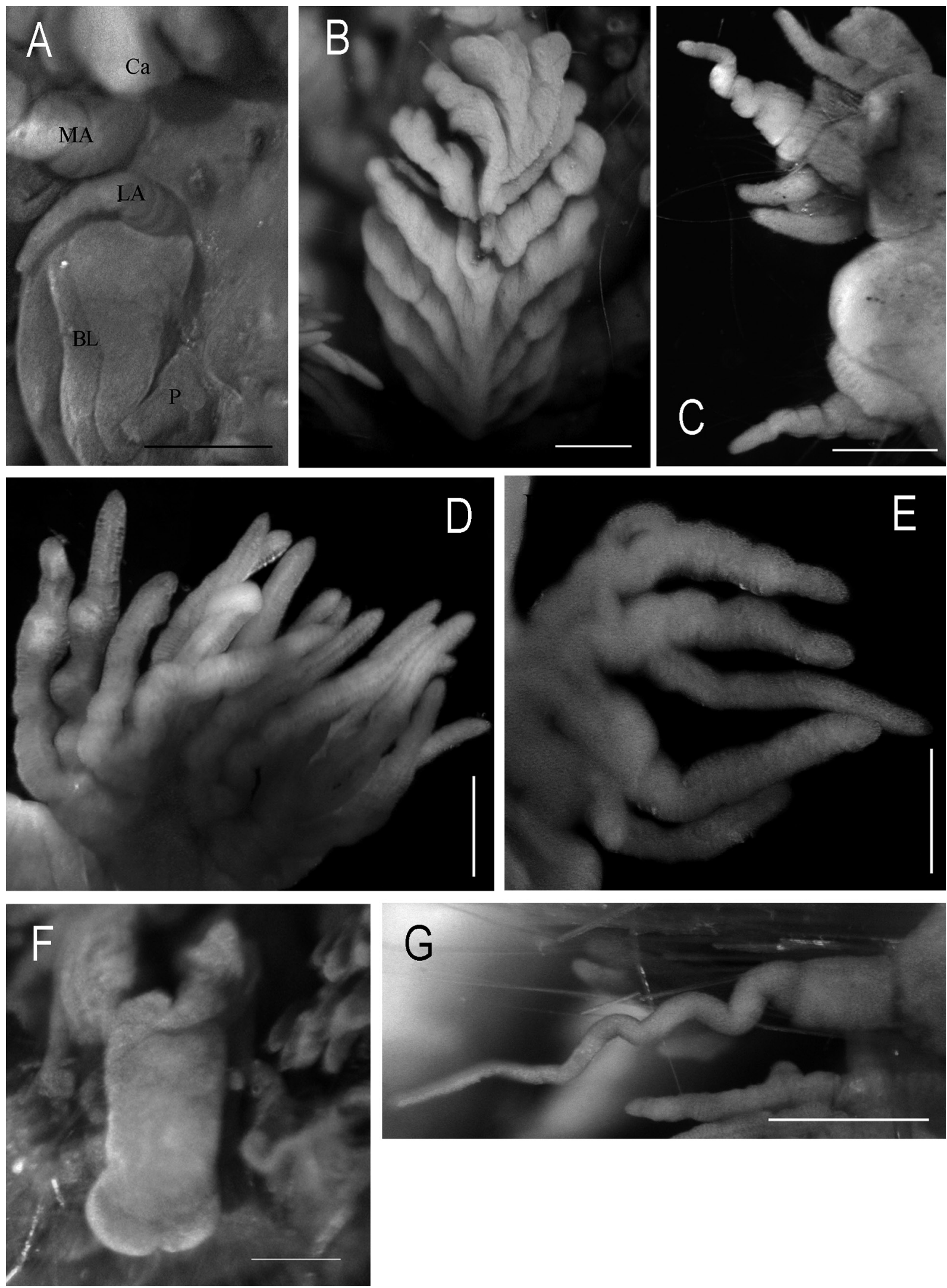

Fig. 6. - Hermodice nigrolineata: A) prostomium, lateral view; B, caruncle, dorsal view; C, parapodium; D, branchial dorsal branch; E, branchial lateral branch; F, anal lobe, view after displacement; G, dorsal cirrus. A, B, C and G scale: 0.5 mm; D, E and F scale: 0.2 mm. Abbreviations: BL, buccal lip; Ca, caruncle; LA, lateral antenna; MA, median antenna; and P, palp. 
The proposal of $H$. carunculata dydimobranchiata Fauvel, 1914, based on specimens from the Gulf of Guinea lacking harpoon chaetae, might correspond to specimens without these chaetae because they have been used as defensive weapons, as some species from those examined here had harpoon chaetae.

Anomalies. Duplication of dorsal cirri (3/37), although one specimen had a triple dorsal cirrus with double cirrophore.

\section{DISCUSSION}

Quatrefages (1866) wondered whether the same species would live in the Caribbean Sea and in the Mediterranean Sea. Although he compared some specimens from the Gulf of Mexico, the Antilles and the Mediterranean coast of Portugal, he could not find any differences. The large, massively muscular body of Hermodice species, which is easily distorted during preservation, makes it quite difficult to observe most species-specific features. Further, as shown above, most useful taxonomic features for other genera are not appropriate for distinguishing between the Hermodice species.

However, our thorough evaluation of the relevant morphological features has allowed us to distinguish between Hermodice carunculata (redefined and restricted to the Grand Caribbean region) and H. nigrolineata (reinstated and distributed in the Mediterranean Sea and adjacent eastern Atlantic Ocean areas). This distinction could be made because, rather than carrying out standard detailed analyses of museum materials, we observed living specimens of $H$. carunculata. This provided information on the natural caruncle modifications, on the effect of preservation on the relative size of appendices, and on the changes in eye shape. Consequently, we could base our conclusions on new taxonomic features (such as the relative number of branchial filaments and the development of the anal lobe) to separate these two similar species.

A finer resolution could be achieved with a molecular approach, and therefore additional cryptic species could be determined. The teleplanic, rostraria larva typical of amphinomids apparently does not guarantee an effective long-distance dispersal and, according to the typical areas of polychaete endemisms (Glasby, 2005), other species might be hidden under the two morphological distinctions described here. A molecular approach might also enhance our understanding of the affinities between these postulated cryptic species, as demonstrated for at least three cryptic species of the fireworm E. complanata found by Barroso et al. (2010). Further relevant data could also be obtained by evaluating color polymorphisms in combination with reproductive biology.

The clear morphological distinction between $H$. carunculata and $H$. nigrolineata implies that a careful evaluation of additional features other than the classi- cal ones could be potentially useful in future studies of the family. However, this type of approach apparently tends to remain in the background of current scientific interests, and is displaced by the growing number of molecular studies. Accordingly, we hope that our study will encourage similar evaluations of closely related species, since there are many pending issues in many problematic polychaete taxa.

\section{Key for Hermodice Kinberg, 1857}

1 Dorsal branchiae with many filaments in median chaetigers (more than 40 in worms with at least 50 chaetigers); anal lobe short, rounded; dorsal, intersegmental, black transverse band sometimes present .................. H. carunculata (Pallas, 1766).

- Dorsal branchiae with few filaments in median chaetigers (less than 20 in worms with at least 50 chaetigers); anal lobe long, bilobed; dorsal, intersegmental, black transverse band always present H. nigrolineata Baird, 1870.

\section{ACKNOWLEDGEMENTS}

This contribution was generated as a part of the MS thesis of BYR in ECOSUR, supported by a scholarship from CONACyT and the project CONACyT 61609. BYR is grateful to Héctor Hernández and Patrick Gillet for their advice. Mariana Tovar, Ann Grant, Axayacatl Molina and Luis Carrera gave us useful recommendations. We extend our thanks to Humberto Bahena for help with photography. The generous help by several curators is acknowledged; Kathryn Ahlfeld (USNM), Melih Cinar (ESFM), Jesús Ángel de León (UANL), Patrick Gillet (IRFA), Leslie Harris (LACM-AHF), Tarik Meziane (MNHN), Jorge Nuñez (DZUL), Emma Sherlock (BMNH), Karin Sindemark (SMNH), Harry ten Hove (ZMA), and Mary Wicksten (TCWC). The comments of Markus Böggemman, Daniel Martin and one anonymous reviewer improved the manuscript and were greatly appreciated.

\section{REFERENCES}

Audouin, J.V. and H. Milne-Edwards. - 1833. Classification des Annélides, et description de celles qu'habitent les côtes de la France. An. Sci. Nat., 28(1): 187-247.

Augener, H. - 1927. Polychaeten von Curaçao. Bijdr. Dierk., 25: $39-82$.

Baird, W. - 1864. Description of a new species of Annelide belonging to the family Amphinomidae. Trans. Linn. Soc. Lond., 24: 449-450.

Baird, W. - 1870. Contributions towards a monograph of the species of Annelides belonging to the Amphinomacea, with a list of the known species, and a description of several new species (belonging to the group) contained in the national collection of the British Museum, to which is appended a short account of two hitherto nondescript annulose animals of a larval character. Trans. Linn. Soc. Lond., 10: 215-250.

Barroso, R., M. Klautau, A.M. Solé-Cava and P.C. Paiva. - 2010. Eurythoe complanata (Polychaeta: Amphinomidae), the 'cosmopolitan' fireworm, consists of at least three cryptic species. Mar. Biol., 157: 69-80. 
Bruguière, L.G. - 1789. Histoire naturelle des Vers. Panckouche, Paris.

Day, J.H. - 1957. The polychaete fauna of South Africa, 4. New species and records from Natal and Mocambique. An. Natal Mus., 14(1): 59-129.

Dean, H.K. - 2004. Marine biodiversity of Costa Rica: Class Polychaeta (Annelida). Rev. Biol. Trop., 52(Suppl. 2): 131-181.

Ebbs, N.K. - 1966. The coral-inhabiting polychaetes of the northern Florida reef tract. Bull. Mar. Sci., 16(3): 485-555.

Ehlers, E. - 1887. Reports on the results of dredging, under the direction of L.F. Pourtalès, during the years 1868-1870, and of Alexander Agassiz, in the Gulf of Mexico (1877-78), and in the Caribbean Sea (1878-79), in the U.S. Coast Survey Steamer "Blake," Lieut. -Com. C.D. Sigsbee, U.S.N., and Commander J.R. Bartlett, U.S.N., Commanding. XXXI. Report on the Annelids. Mem. Mus. Comp. Zool. Harvard Coll., 15: 1-335.

Fauchald, K. - 1977. The polychaete worms: Definitions and keys to the orders, families and genera. Nat. Hist. Mus. Los Ang. Count. Sci. Ser., 28: 1-190.

Fauvel, P. - 1914. Annélides polychaètes de San-Thomé (Golfe de Guinée) recuilles par M. Ch. Gravier. Arch. Zool. Exp. Gen., 54(5): 105-155.

Fauvel, P. - 1923. Polychètes errantes. Faune de France. Paul Lechevalier. Paris.

Fauvel, P. and F. Rullier. - 1959. Annélides polychètes. Resultats Scientifiques des Campagnes de Calypso 4. An. Inst. Oceanogr., 37: 143-205.

Glasby, C.J. - 2005. Polychaete distribution patterns revisited: an historical explanation. Mar. Ecol., 26(3-4): 235-245.

Gustafson, G. - 1930. Anatomische Studien über die PolychätenFamilien Amphinomidae und Euphrosynidae. Zool. Bidrag Uppsala, 12: 301-471.

Hartman, O. - 1949. The marine annelids erected by Kinberg with notes on some others types in the Swedish State Museum. Arkiv. Zool., 42A(1): 1-137.

Hartman, O. - 1951. The littoral marine annelids of the Gulf of Mexico. Publ. Inst. Mar. Sci., 2(1): 7-124.

Hartman, O. - 1959. Catalogue of the Polychaetous Annelids of the World, Pt. 1. Allan Hancock Occas. Pap., 23: 1-353.

Harvey, P.H. and M.D. Pagel. - 1991. The comparative method in evolutionary biology. Oxford Univ. Press, Oxford.

Horst, R. - 1886. Contributions towards the knowledge of the annelida Polychaete. Notes Leyden Mus., 8: 157-174.

Horst, R. - 1911. On the synonymy of Pherecardia lobata Horst. Notes Leyden Mus., 34: 17-21.

Ibarzábal, D. - 1989. Poliquetos de Punta del este, Isla de la juventud, Cuba. Poeyana 374: 1-19.

Kinberg, J.G.H. - 1857. Nya slägten och arter af Annelider, 2. Amphinomea. Öfversigt Kongl. Vetensk.-Akad. Förhandlingar, 14(1): $11-14$

Kinberg, J.G.H. - 1867. Om Amphinomernas systematik. Öfversigt Kongl. Vetensk.-Akad. Förhandlingar, 24(3): 83-91.

Kinberg, J.G.H. - 1910. Annulater. Kongliga Svenska Fregatten Eugenies Resa omkring jorden under befäl af C.A. Virgin aren 1851-1853, 7: 33-78, Pls. 9-29. Almquist \& Wiksells. Uppsala \& Stockholm.

Kudenov, J.D. - 1974. The reproductive biology of Eurythoe complanata (Pallas, 1766), (Polychaeta: Amphinomidae). Ph. D. thesis, Univ. Arizona.

Kudenov, J.D. - 1995. Family Amphinomidae Lamarck, 1818. In: J.A. Blake, B. Hilbig and P.H. Scott (eds.) Taxonomic Atlas of the Benthic Fauna of the Santa Maria Basin and Western Santa Barbara Channel, pp. 207-215. Santa Barbara Museum of Natural History, California.
Liñero-Arana, I. - 1993. Anélidos poliquetos de la costa nororiental de Venezuela. Bol. Inst. Oceanogr. Venez., 32: 17-26.

Marsden, J.R. and M. Galloway. - 1968. The micro-anatomy of the supraoesophageal ganglion of Eurythoe complanata. Can. J. Zool., 46(3): 349-376.

McIntosh, W.C. - 1885. Report on the Annelida Polychæta collected by H.M.S. Challenger during the years 1873-76. Challenger Rep., 12: 1-554.

Monterroso, O., J. Núñez and R. Riera. - 2004. Macrofauna de fondos blandos en las concesiones de acuicultura de la Bahía de Igueste de San Andrés, Tenerife. Rev. Acad. Canaria Cien., 15(3-4): 77-86

Monro, C.C.A. - 1930. Polychaete worms. Discovery Rep., 2: 1-222.

Nuñez, J., M.C. Brito and O. Ocaña. - 1991. Anélidos poliquetos de Canarias: familia Amphinomidae. Cah. Biol. Mar., 32(4): 469-476.

Pallas, P.S. - 1766. Miscellanea Zoologica, Hagae Comitum.

Quatrefages, A. de - 1866. Histoire Naturelle des Annelés Marins et d'Eau Douce. Annélides et Géphyriens. Librairie Encyclopédique de Roret, Paris. 3 vols. and Atlas with Pls. 1-20. [erroneously dated 1865, but according to Wright (1867): “.|.|. was not published until the summer of 1866"].

Rullier, F. - 1964. Contribution à la faune des annélides polychaètes du Cameroun. Bull. Inst. Fr. Afr. Noire, 26(4): 1071-1102.

Salazar-Vallejo, S.I. - 1997. Anfinómidos y eufrosínidos (Polychaeta) del Caribe mexicano con claves para las especies reconocidas del Gran Caribe. Rev. Biol. Trop., 45(1): 379-390.

Salazar-Vallejo, S.I. and M.H. Londoño-Mesa. - 2004. Lista de especies y bibliografía de poliquetos (Polychaeta) del Pacífico Oriental Tropical. An. Inst. Biol. Univ. Nac. Auton. Mex. Zool., 75(1): 9-97.

Savigny, J.C. - 1822. Système des Annélides, principalement de celles des côtes de l'Egypte et de la Syrie, offrant les caractères tant distinctifs que naturelles des Ordres, Familles et Genres, avec la Description des Espèces. Description de L'Egypte. Histoire naturelle, Paris, Panckouche 21: 325-472 (Dated 1809, but first issued in 1820; a second edition in 1826. Also in Oken's Isis, vol. for 1832 , pp. 938-955 and 961-966, pls. 19-25. However, after Opinion 1461, Bull. Zool Nomencl. 44: 219-220, its publication date has fixed as 1822).

Schmarda, L.K. - 1861. Neue wirbellose Thiere beobachtet und gesammelt auf einer Reise um die Erde 1853 bis 1857. Wilhelm Engelman, Leipzig.

Tebble, N. - 1955. The polychaete fauna of the Gold Coast. Bull. Br. Mus., 3: 59-148.

Tovar-Hernández, M.A. and S.I. Salazar-Vallejo. - 2008. Caruncle in Megalomma Johansson, 1925 (Polychaeta: Sabellidae) and the description of a new species from the Eastern Tropical Pacific. J. Nat. Hist., 42(29-30): 1951-1973.

Treadwell, A.L. - 1939. Polychaetous annelids of Porto Rico and vicinity. Sci. Surv. P. R. Virgin Isls., 16: 150-319.

Treadwell, A.L. - 1941. Polychaetous annelids from the West Coast of Mexico and Central America. Zool. Sci. Contrib. N. Y. Zool. Soc., 26: 17-24

Wiklund, H., A. Nygren, F. Pleijel and P. Sundberg. - 2008. The phylogenetic relationships between Amphinomidae, Archinomidae and Euphrosinidae (Amphinomida: Aciculata: Polychaeta), inferred from molecular data. J. Mar. Biol. Ass. U. K., 88(3): 509-513.

Scient. ed.: D. Martin.

Received December 12, 2009. Accepted September 13, 2010.

Published online March 8, 2011. 